Agro-Science Journal of Tropical Agriculture, Food, Environment and Extension Volume 21 Number 1 (January 2022) pp. 27 - 33

ISSN 1119-7455

\title{
LABEL INFORMATION, NUTRITIONAL COMPOSITION AND SCREENING FOR BROMATE IN BREADS SOLD IN UMUAHIA, ABIA STATE, NIGERIA
}

\author{
${ }^{1}$ Ugwuona F.U., ${ }^{2}$ Asogwa I.S., *2 Obeta N.A. and ${ }^{1}$ Okeke F.N. \\ ${ }^{1}$ Department of Food Science \& Technology, \\ Michael Okpara University of Agriculture, Umudike, Abia State, Nigeria \\ ${ }^{2}$ Department of Food Science \& Technology, University of Nigeria, Nsukka, Enugu State, Nigeria \\ *Corresponding author's email: nwamaka.obet@unn.edu.ng
}

\begin{abstract}
Non-use of potassium bromate in bread making and printing of reproducible nutrition information/claims on bread labels are vital for consumers' rights and protection in Nigeria. These norms are rarely observed by bread makers in Umuahia. This study evaluated nutrition information on labels, presence of potassium bromate, chemical composition and sensory characteristics of breads sold in Umuahia. Two structured questionnaires were constructed. The first was administered to 15 randomly selected full-time bread vendors in Umuahia metropolis to identify brands of market bread. The second was designed to analyze sensory quality of breads. Five sliced and five unsliced bread samples randomly selected from identified markets were analyzed for sensory properties using a 20-member sensory panelist, and for nutrient and phytochemical composition. Twenty-seven bread samples were identified; all labeled bromate-free, had varying recipes and nutrient claim/information on labels. The bread samples were bromate-free, high in carbohydrate (49.20\% in B10 to $65.69 \%$ in B8) and moisture (22.67\% in B8 to 38.16\% in B10), but relatively low in crude protein (6.65\% in B3 to $9.45 \%$ in B7) and fat $(0.26 \%$ in $B 8$ to $0.66 \%$ in $B 1)$. Ash contents ranged from $1.26 \%$ in $B 6$ to $1.86 \%$ in B3and fiber contents from $1.24 \%$ in $B 2$ to $1.76 \%$ in B5. Phytonutrients were low; and oxalate content ranged from 0.66 to $0.95 \%$,

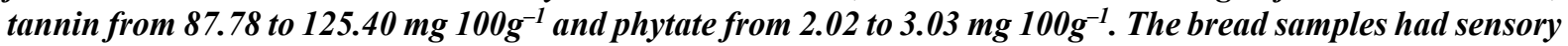
scores ranging from 4.60 to 8.10 for over-all acceptability. They were all acceptable to panelists, but with B1 (sliced) and $B 8$ (unsliced) most acceptable. Bread samples sold in Umuahia were bromate-free, varied in recipe, nutrition claims, and nutrient composition but were acceptable to panelists.
\end{abstract}

Key words: market bread, Umuahia, label information, bromate-free, quality

\section{INTRODUCTION}

Bread is one of the most widely consumed food products globally and bread making technology is probably one of the oldest technologies known (Ebuchi and Oyewole, 2007; Selomulyo and Zhou, 2007). In Nigeria, it is consumed by people of different socio- economic class, and is acceptable to both children and adults (Onuegbu et al., 2007). The demand is increasing as people are changing from traditional patterns of eating three meal courses at home per day to eating of snack foods such as bread and biscuits as breakfast and lunch outside homes (Anyika and Uwaegbute, 2005). This habit is most common incities where bread is used as a convenient food (Anyika and Uwaegbute, 2005; Kansas, 2006).

This astronomical increase in consumption of bread in the country has subsequently spurred many Nigerians to go into bread manufacture. New mills are being established everyday while the already existing millers are making sizeable capital investments to expand their milling capacity to meet the ever-increasing demand for flours. This has made Nigerian government to increase importation of wheat into the country (Edema et al., 2004; Michael, 2006); and has also made it compulsory that at least $10 \%$ of cassava should be incorporated to bakery flours produced in the country (SON, 2004). This was to reduce revenue on wheat importation, increase local content in bread and reduce unit cost of bread for Nigerians.

Today, bakery operations are being modernized and expanded to satisfy growing demand for bread. Subsequently, new brands of bread with varying nutrient compositions, textures, appearance, crumbs, tastes and costs are springing up every day from old and new bread factories in the country. Some brands of bread do not have recipes and nutrition information on their labels, and this information on those that have it vary widely. Also, most of these breads inscribe, 'bromate-free' on their labels, implying that they have no bromate. Factual and reproducible information should be given to the consumers for their rights and protection against food allergy and infection.

Please cite as: Ugwuona F.U., Asogwa I.S., Obeta N.A. and Okeke F.N. (2022). Label information, nutritional composition and screening for bromate in breads sold in Umuahia, Abia State, Nigeria. Agro-Science, 21 (1), 27-32. DOI: https://dx.doi.org/10.4314/as.v21i1.5 
Over the years, potassium bromate has been used as an important bread improver. Potassium bromate helps to hold bread dough together, enhance its elasticity, promotes bread swelling and also makes the bread to be fluffy and soft - qualities that attract customers. However, recent toxicity tests showed that potassium bromate could induce carcinogenicity in laboratory animals. As a follow up, the country's apex drug and food regulatory agency, the National Agency for Food and Drug Administration and Control (NAFDAC) in 2004 banned the use of bromate in bread making and other edible products (Ekpo et al., 2008, Emeje et al., 2010). Also, Standard Organization of Nigeria (SON) has set standing specifications and standards to regulate good manufacturing practice (GMP) and quality of breads produced and sold in Nigerian (Kansas, 2006; Emeje et al., 2010; Onuegbu et al., 2013). All these measures are to protect rights and health of consumers.

Some bread manufacturers that are not professionals may under-estimate the danger of slow killers in foods and food poisoning. Such manufacturers may still be using bromate and compromising in quality. The information on their bread labels may not be factual and reproducible. This study evaluated label information, chemical composition, safety and sensory characteristics of bread samples sold in Umuahia, Abia State, Nigeria.

\section{MATERIALS AND METHODS}

\section{Location and Population for the Study}

The location of study was Umuahia, capital of Abia State, Nigeria. A total of 37 brands of commercial bread were identified as marketed in Umuahia metropolis, Abia State, Nigeria.

Sample Collection and Preparation for the Study Prior to analysis, 10 out of the 37 brands of bread were randomly selected. They were purchased from the distributing vans, tightly packed, and transferred to the laboratory and stored in the refrigerator $\left(4^{\circ} \mathrm{C}\right)$ until used for physicochemical and sensory analysis.

\section{Determination of Nutrient Composition of Bread Samples}

Moisture, crude fat, protein, fiber and ash contents were determined using AOAC (2005) method. Moisture content was recorded as the average percentage loss in weight after drying $2 \mathrm{~g}$ of bread sample in triplicates at $105^{\circ} \mathrm{C}$ for $4 \mathrm{~h}$ in a hot air oven. Crude protein content of the bread samples was determined using the Kjeldahl nitrogen assay $(\mathrm{N} \times 6.25)$ method of AOAC (2005). Crude fat content was reported as a percentage loss in weight after exhaustively extracting $2 \mathrm{~g}$ of bread with $\mathrm{n}$ hexane as the extracting solvent using Soxhlet apparatus. Crude fiber content was calculated as the percentage loss of the $2 \mathrm{~g}$ sample after subsequently digesting the fat-free residue with $1.25 \%$ each of $\mathrm{H}_{2} \mathrm{SO}_{4}$ and $\mathrm{NaOH}$ solutions. Ash content was determined by incinerating $2 \mathrm{~g}$ of a finely ground bread sample in a muffle furnace at $550^{\circ} \mathrm{C}$; and the residue expressed as a percentage ash content of the bread sample. Carbohydrate content was determined by difference, after subtracting the sum of moisture, crude protein, fat, fiber, and ash contents from 100.

\section{Determination of Minerals}

The residue after incinerating $2 \mathrm{~g}$ of each bread sample at $600^{\circ} \mathrm{C}$ for $2 \mathrm{~h}$ in a muffle furnace was recorded as the ash content and used to prepare standard ash solution. The standard ash solution was used to determine calcium, iron, zinc and magnesium contents of the breads using atomic absorption spectrophotometer (AAS) while phosphorus content was determined using the vanado-molybdate method (AOAC, 2005).

\section{Determination of Potassium Bromate Content of Bread Samples}

First, a solution of $0.5 \%$ potassium iodide in $2 \mathrm{M} \mathrm{HCl}$ solution was poured over a $15 \mathrm{~mm}$ thick slab of compressed bread sample. Formation of black sports of potassium bromate on the bread suggests presence of bromate. Further iodometric titration (Kirk and Sawyer, 1991) was used for quantitative determination of bromated in the bread samples. Furthermore, slices of $15 \mathrm{~mm}$ thick and $2 \mathrm{~cm}$ in diameter cut from centre of each bread sample were dried at $55^{\circ} \mathrm{C}$ for $72 \mathrm{~h}$ in a hot air oven. The crusts were ground to fine powder, $5 \mathrm{~g}$ of each mixed with $200 \mathrm{ml}$ of distilled water and stirred vigorously for 2 min. in a $250 \mathrm{ml}$ beaker. Then, $2 \mathrm{ml}$ of each of the supernatants were added to $2.5 \mathrm{ml}$ of congo red in the first test tubes and to $2.5 \mathrm{ml}$ crystal violet indicator in the second test tubes. To each of the text tubes were added $5 \mathrm{ml}$ of $2 \mathrm{M} \mathrm{HCl}$ and $2 \mathrm{ml}$ of distilled water. Each tube was shaken vigorously, allowed to rest for $5 \mathrm{~min}$., and absorbance of the supernatants from the congo red was read at $485 \mathrm{~nm}$ while those of the crystal violet indicator was read at $552 \mathrm{~nm}$.

\section{Determination of Phytochemical Contents}

\section{Determination of oxalate content}

Oxalate content was determined as described by Oke (1966). One gram of mashed bread sample was mixed with $190 \mathrm{ml}$ of de-ionized water and $10 \mathrm{ml}$ of $6 \mathrm{M}$ hydrochloric acid. This was digested at $90^{\circ} \mathrm{C}$ for $4 \mathrm{~h}$, centrifuged at $2000 \mathrm{rpm}$ for $5 \mathrm{~min}$. and the supernatant diluted to $250 \mathrm{ml}$ with distilled water. This was titrated with concentrated ammonium hydroxide solution, using methyl orange indicator, until the pink coloration changed to an endpoint faint yellow colour. The resultant mixture was heated $\left(90^{\circ} \mathrm{C}, 20\right.$ min.) and mixed with $10 \mathrm{ml}$ of $5 \% \mathrm{CaCl}_{2}$ solution. This was rested overnight, centrifuged (at $2000 \mathrm{rpm}$ for $5 \mathrm{~min}$.) and decanted to get the precipitated calcium oxalate. The oxalate was oven-dried at $60^{\circ} \mathrm{C}$ for $48 \mathrm{~h}$, cooled and then weighed. This process was done in triplicate and the mean weight expressed as: 
Oxalate content $(\%)=\frac{\text { Weight of oxalate }}{\text { Wieght of sample }} \times 100$

\section{Determination of tannin content}

Tannin content was determined using the vanillin$\mathrm{HCl}$ method described by Niseteo et al. (2012). One gram of each sample was mixed vigorously with 10 $\mathrm{ml}$ of methanol at room temperature $\left(28 \pm 2^{\circ} \mathrm{C}\right)$ and allowed to extract for $1 \mathrm{~min}$. This was filtered, and $3 \mathrm{ml}$ of the extract reacted with $3 \mathrm{ml}$ of $0.1 \mathrm{ml} \mathrm{NH}_{4} \mathrm{Cl}$ and $3 \mathrm{ml}$ of $0.08 \mathrm{ml} \mathrm{K}_{3} \mathrm{Fe}(\mathrm{CN})_{6}$. This was done in triplicates. The absorbance was read at $720 \mathrm{~mm}$, and tannin content extrapolated from a standard curve previously prepared with catechin as tannin standard.

\section{Determination of phytate content}

Phytate content was determined according to the method of AOAC (2005). Mashed bread sample $(4.0 \mathrm{~g})$ was soaked in $100 \mathrm{ml}$ of $2.4 \% \mathrm{HCl}$ for $3 \mathrm{~h}$ at room temperature $\left(28 \pm 2^{\circ} \mathrm{C}\right)$ and then filtered through Whatman No. 2 filter paper. Twenty-five $\mathrm{ml}$ of the filtrate was pipetted into $50 \mathrm{ml}$ conical flask; and 5 $\mathrm{ml}$ of $0.3 \%$ ammonium thiocyanate solution and $53.5 \mathrm{ml}$ of distilled water added. The mixture was titrated against standard iron (III) chloride solution (containing $0.00195 \mathrm{~g} \mathrm{Fe}^{3+} \mathrm{ml}^{-1}$ ) until a brownish yellow colour lasted for $5 \mathrm{~min}$. Phytate content was expressed as percentage phytate in the bread sample.

\section{Sensory Analysis}

Sensory analysis was done according to the method of Meilgaard et al. (1999). Sixteen-member panelists randomly drawn from staff and 500 level students of the Department of Food Sciences and Technology of Michael Okpara University of Agriculture, Umudike did the sensory analysis. Five slices ( $2 \mathrm{~mm}$ thick) of each bread sample on randomly three-digit coded white saucers were presented to the panelists at the Food Processing Laboratory of the Department to evaluate for crust appearance, crumb appearance, flavour, taste and overall acceptability for each bread sample, using a 9-point hedonic scale (1: extremely disliked to 9: extremely liked). Breads scored 5 and above for overall acceptability.

\section{Statistical Analysis}

Data were subjected to descriptive statistics and analysis of variance was used to compare differences among means. Means with significant $(p<0.05)$ difference were separated with Duncan's multiple range test using SPSS Version 16 (SPSS, 2007).

\section{RESULTS AND DISCUSSION}

Manufactures' Recipes on Labels of Bread Sold in Umuahia Metropolis of Abia State, Nigeria

Table 1 shows manufactures' recipes of 10 bread samples. Nine of them used whole wheat flour as the base ingredient, while one (B8) used malted wheat and barley flours as the base ingredient for the bread making. Two of the breads' recipe (B7 and B9) added wheat gluten. Three bread samples, B5, B6 and B9, added soy flour as protein enrichment in their recipes.

Recipe for sample B2 contained milk and egg yolk while recipe $\mathrm{B} 7$ contained only milk in its recipe for protein enrichment. In the recipe for B3, margarine was used. Vegetable oil was used in samples B5 and B9 while hydrogenated fat was used in the remaining seven as shortening. Margarine is hydrogenated fat with added vitamins and minerals.

Water was not indicated in the recipes. Wheat automatically needs liquid, either as milk or water, to form dough. Also, none of the recipes indicated presence of cassava flour in their recipes. This is also practically incorrect when at least $10 \%$ of cassava flour is compulsorily added to all commercial bakery flours in Nigeria. All the recipes had yeast included in them. Of course, yeast is the active ingredient in bread making as it actively ferments sugars in the dough (Rose and Vijayalakshmi, 1993; Randez-Gil et al., 1999; Poitrenaud, 2004; Cauvain, 2015). The recipe for sample B3 contained honey while the rest of the recipe contained sucrose (table sugar) as sweetener. All the recipes except B5 added ascorbic acid in their bread. Ascorbic acid acts as improver in place of potassium bromate. Also, all the recipes except recipe B8 had salt. Salt acts as a flavour enhancer, preservative and also as dough improver (Brown, 1993; Doyle and Glass, 2010). Dried mixed

Table 1: Manufactures' recipes on labels of bread samples sold in Umuahia metropolis of Abia State, Nigeria

\begin{tabular}{|c|c|c|c|c|c|c|c|c|c|c|}
\hline Ingredients & $\mathrm{B} 1$ & $\mathrm{~B} 2$ & B3 & B4 & $\mathrm{B} 5$ & B6 & B7 & B8 & B9 & $\mathrm{B} 10$ \\
\hline Whole wheat flour & $\mathrm{A}$ & $\mathrm{A}$ & $\mathrm{A}$ & $\mathrm{A}$ & $\mathrm{A}$ & $\mathrm{A}$ & $\mathrm{A}$ & $\mathrm{A}$ & $\mathrm{A}$ & $\mathrm{A}$ \\
\hline Malted wheat flour & NA & NA & NA & NA & NA & NA & NA & A & NA & NA \\
\hline Malted barley flour & NA & NA & NA & NA & NA & A & A & $\mathrm{A}$ & NA & NA \\
\hline Wheat gluten & NA & NA & NA & NA & NA & NA & A & NA & A & NA \\
\hline Soy flour & NA & NA & NA & NA & A & A & NA & NA & NA & A \\
\hline Vegetable fat & $\mathrm{A}$ & $\mathrm{A}$ & NA & $\mathrm{A}$ & NA & A & $\mathrm{A}$ & $\mathrm{A}$ & NA & NA \\
\hline Vegetable oil & NA & NA & NA & NA & A & NA & NA & NA & A & NA \\
\hline Margarine & NA & NA & A & NA & NA & NA & NA & NA & NA & NA \\
\hline Sugar & A & NA & A & A & A & A & A & A & A & A \\
\hline Honey & NA & A & NA & NA & NA & NA & NA & NA & $\mathrm{A}$ & NA \\
\hline Water & NA & NA & NA & NA & NA & NA & NA & NA & NA & NA \\
\hline Milk & NA & A & NA & NA & NA & NA & A & NA & NA & NA \\
\hline Whole egg & NA & NA & NA & NA & & NA & A & NA & NA & NA \\
\hline Egg yolk & NA & A & NA & NA & NA & NA & NA & NA & NA & NA \\
\hline Egg yellow & NA & NA & NA & NA & NA & NA & NA & NA & A & NA \\
\hline Yeast & A & A & A & A & A & A & A & A & A & A \\
\hline Ascorbic acid & $\mathrm{A}$ & A & A & $\mathrm{A}$ & NA & A & $\mathrm{A}$ & $\mathrm{A}$ & A & A \\
\hline Salt & $\mathrm{A}$ & A & $\mathrm{A}$ & A & A & A & A & NA & A & A \\
\hline Dried mixed fruit & NA & NA & NA & $\mathrm{A}$ & NA & $\mathrm{A}$ & NA & NA & NA & $\mathrm{A}$ \\
\hline Calcium propionate & A & NA & A & NA & A & NA & NA & NA & A & NA \\
\hline
\end{tabular}

$\mathrm{A}$ - added in recipe, NA - not added in recipe, B1-B10 - bread samples of different brands 
fruit was added in recipes B4, B6 and B10. Fruit mixes add micronutrients and flavours to bread. Recipes B1, B3, B5 and B9 added calcium propionate in their recipes. Propionate and propionic acid are broad spectrum antimicrobial agents, and inhibit growth of bacteria, yeasts and molds in bread (Brown, 1993; Cauvain, 2015).

\section{Nutrition Information on Labels of Bread Sold in Umuahia Metropolis, Abia State, Nigeria}

Table 2 shows the nutrition information on labels of samples of the ten randomly selected bread samples. The label information showed that the bread samples were high in energy, moderate in protein but poor in most vitamins and mineral contents. The energy value (kCal) ranged from 119 in B3 to 350 in B2 and B6, confirming bread as a good source of energy.

Carbohydrate content (\%) ranged from 8.0 in B7 to 50.4 in B9. Invert sugar (\%) ranged from 0.1 in $\mathrm{B} 4$ and $\mathrm{B} 10$ to 10.2 in $\mathrm{B} 2$ and $\mathrm{B} 6$, but it was not determined in $\mathrm{B} 3$ and $\mathrm{B} 7$. The $0.1 \%$ invert sugar in $\mathrm{B} 4$ and B10 probably means that no invert sugar was added in the recipe but suggested that it was not determined in the bread samples. The protein content (\%) ranged from 8.0 in $\mathrm{B} 7$ to 15.0 in $\mathrm{B} 3$. Protein content in samples B4, B5, B7, B8 and B10 were lower than $10 \%$ while samples B1, B2, B3, B5 and B9 had protein content of $10 \%$ and above. The fat content (\%) ranged from as low as 1 in B5 to as high as 12.1 in $\mathrm{B} 2$ and B6. Based on the nutrition information, bread samples B2, B4, B6 and B10 could be regarded as fatty when compared with the others. The presence and composition of fat, carbohydrate and protein in food determines its energy value; and foods high in fat and carbohydrate are termed energy foods. Bread, of course, is an energy food. Fiber content (\%) ranged from as low as 0.69 in B10 to as high as 4.0 in B5. The bread samples B9 with $2.9 \%$ fiber, B8 with $3.5 \%$ fiber, B7 with $3.76 \%$ fiber, and B5 with $4.0 \%$ fiber could be regarded as high fiber breads if actually these values are reflected in the results of proximate composition of the breads. Micronutrient contents, analyzed in few samples, as shown on the labels were generally poor in the bread samples. It was only samples B1, B5 and B9 that had most of these micronutrients on the labels.

\section{Proximate Composition of the Bread Samples}

Table 3 shows proximate composition of 10 randomly selected brands of breads. Moisture content of the bread samples differed significantly $(p<0.05)$ and ranged from 22.67 in B8 to $38.16 \%$ in B8. Moisture contents of all the bread samples were lower than $40 \%$ maximal moisture content standard permitted by the Standard Organization of Nigeria (SON, 2004). Ebuehi et al. (2007) reported low moisture contents of $18.8-27.6 \%$ for bread samples sold in the same Umuahia Metropolis. On the other hand, Eke et al. (2013) reported higher moisture content of 30.21 to $34.07 \%$ in breads sold

Table 2: Nutrition claims on labels of bread samples sold in Umuahia metropolis of Abia State, Nigeria

\begin{tabular}{|c|c|c|c|c|c|c|c|c|c|c|}
\hline Nutrients & B1 & B2 & B3 & B4 & B5 & B6 & B7 & B8 & B9 & B10 \\
\hline \multicolumn{11}{|l|}{ Proximate } \\
\hline Total carbohydrate (\%) & 48.00 & 35.10 & 36.70 & 37.30 & 29.00 & 35.10 & 8.00 & 43.10 & 50.40 & 37.30 \\
\hline Dietary fiber (\%) & 1.20 & 0.70 & 0.70 & 0.68 & 4.00 & 0.70 & 3.76 & 3.50 & 2.90 & 0.68 \\
\hline Protein (\%) & 12.00 & 10.50 & 15.00 & 9.00 & 9.00 & 10.50 & 8.00 & 8.70 & 10.90 & 9.00 \\
\hline Total fat (\%) & 2.50 & 12.10 & 2.00 & 10.50 & 1.00 & 12.10 & 3.60 & 2.70 & 6.10 & 10.50 \\
\hline Invert sugar $\left(\mathrm{mg} 100 \mathrm{~g}^{-1}\right)$ & 4.00 & 10.20 & ND & 0.10 & 1.00 & 10.20 & ND & 3.40 & 3.90 & 0.10 \\
\hline Energy $(\mathrm{kCal})$ & 120.00 & 350.00 & 119.00 & 327.00 & ND & 350.00 & 305.00 & 250.00 & 300.00 & 327.00 \\
\hline \multicolumn{11}{|l|}{ Minerals $\left(\mathrm{mg}_{\left.100 \mathrm{~g}^{-1}\right)}\right.$} \\
\hline Calcium & 1.40 & 154.00 & ND & 153.00 & 4.0 & 154.00 & ND & ND & 1.40 & 153.00 \\
\hline Sodium & 0.90 & ND & 1.0 & ND & 5.0 & ND & ND & 8.43 & 0.80 & ND \\
\hline Magnesium & 0.31 & ND & ND & ND & ND & ND & ND & ND & 0.32 & ND \\
\hline Iron & 5.40 & ND & ND & ND & 6.0 & ND & ND & ND & 5.40 & ND \\
\hline Phosphorus & ND & ND & ND & ND & ND & ND & ND & ND & 0.60 & ND \\
\hline \multicolumn{11}{|l|}{ Vitamins (IU) } \\
\hline Vitamin A & 1200.00 & ND & ND & ND & 0.00 & ND & ND & ND & 1200.00 & ND \\
\hline Ascorbic acid & 19.50 & ND & ND & ND & 0.00 & ND & ND & ND & 19.50 & ND \\
\hline Niacin & ND & ND & ND & ND & 6.00 & ND & ND & ND & ND & ND \\
\hline Folate & ND & ND & ND & ND & 8.00 & ND & ND & ND & ND & ND \\
\hline
\end{tabular}

ND - not determined, B1-B10 - bread samples of different brands

Table 3: Proximate composition of bread samples consumed in Umuahia metropolis of Abia State, Nigeria

\begin{tabular}{lllllll}
\hline Samples $^{*}$ & Moisture (\%) & Ash $(\%)$ & Fat $(\%)$ & Protein $(\%)$ & \multicolumn{2}{c}{ Fiber $(\%)$} \\
\hline B1 & $34.15 \pm 0.00^{\mathrm{bc}}$ & $1.35 \pm 0.00^{\mathrm{f}}$ & $0.66 \pm 0.00^{\mathrm{a}}$ & $8.32 \pm 0.00^{\mathrm{c}}$ & $1.36 \pm 0.00^{\mathrm{c}}$ & Carbohydrate $(\%)^{\mathrm{c}}$ \\
B2 & $35.72 \pm 0.01^{\mathrm{b}}$ & $1.64 \pm 0.00^{\mathrm{c}}$ & $0.50 \pm 0.00^{\mathrm{d}}$ & $7.63 \pm 0.01^{\mathrm{d}}$ & $1.24 \pm 0.00^{\mathrm{d}}$ & $53.29 \pm 0.02^{\mathrm{e}}$ \\
B3 & $28.92 \pm 0.01^{\mathrm{f}}$ & $1.86 \pm 0.00^{\mathrm{a}}$ & $0.29 \pm 0.00^{\mathrm{g}}$ & $6.65 \pm 0.00^{\mathrm{e}}$ & $1.36 \pm 0.00^{\mathrm{c}}$ & $60.92 \pm 0.02^{\mathrm{b}}$ \\
B4 & $31.16 \pm 0.01^{\mathrm{d}}$ & $1.49 \pm 0.00^{\mathrm{de}}$ & $0.57 \pm 0.00^{\mathrm{c}}$ & $7.23 \pm 0.01^{\mathrm{e}}$ & $1.45 \pm 0.00^{\mathrm{bc}}$ & $58.10 \pm 0.01^{\mathrm{c}}$ \\
B5 & $28.35 \pm 0.00^{\mathrm{f}}$ & $1.53 \pm 0.00^{\mathrm{d}}$ & $0.49 \pm 0.00^{\mathrm{d}}$ & $8.06 \pm 0.00^{\mathrm{d}}$ & $1.76 \pm 0.00^{\mathrm{a}}$ & $59.82 \pm 0.01^{\mathrm{b}}$ \\
B6 & $30.76 \pm 0.01^{\mathrm{de}}$ & $1.26 \pm 0.00^{\mathrm{g}}$ & $0.43 \pm 0.00^{\mathrm{e}}$ & $7.63 \pm 0.00^{\mathrm{d}}$ & $1.39 \pm 0.00^{\mathrm{c}}$ & $58.53 \pm 0.01^{\mathrm{c}}$ \\
B7 & $29.75 \pm 0.00^{\mathrm{e}}$ & $1.84 \pm 0.00^{\mathrm{a}}$ & $0.66 \pm 0.00^{\mathrm{a}}$ & $9.45 \pm 0.00^{\mathrm{a}}$ & $1.26 \pm 0.00^{\mathrm{d}}$ & $57.03 \pm 0.01^{\mathrm{d}}$ \\
B8 & $22.67 \pm 0.00^{\mathrm{g}}$ & $1.66 \pm 0.00^{\mathrm{c}}$ & $0.26 \pm 0.01^{\mathrm{f}}$ & $8.15 \pm 0.01^{\mathrm{cd}}$ & $1.57 \pm 0.00^{\mathrm{b}}$ & $65.69 \pm 0.01^{\mathrm{a}}$ \\
B9 & $35.23 \pm 0.00^{\mathrm{b}}$ & $1.74 \pm 0.00^{\mathrm{b}}$ & $0.63 \pm 0.00^{\mathrm{b}}$ & $7.79 \pm 0.00^{\mathrm{d}}$ & $1.48 \pm 0.00^{\mathrm{b}}$ & $53.12 \pm 0.01^{\mathrm{d}}$ \\
B10 & $38.16 \pm 0.00^{\mathrm{a}}$ & $1.61 \pm 0.01^{\mathrm{c}}$ & $0.49 \pm 0.00^{\mathrm{d}}$ & $8.85 \pm 0.01^{\mathrm{b}}$ & $1.55 \pm 0.00^{\mathrm{b}}$ & $49.20 \pm 0.01^{\mathrm{j}}$ \\
\hline
\end{tabular}

"mean values and standard deviations of 3 determinations, a b c d e f g j - mean values with the same superscripts in a column are not significantly $(p>0.05)$ different, B1-B10 - bread samples of different brands 
in Benue and Nassarawa States of Nigeria. Moisture contents influence sensory, physical and microbial quality of breads (Olaoye et al., 2006). Okafor et al. (2012) also reported a comparable value of $32.60 \%$ moisture content for white bread sold in Nigeria while Ortega et al. (2013) reported moisture content of $34.9 \%$ for white bread sold in Europe.

Protein content $(\%)$ significantly $(p<0.05)$ differed among the bread samples, and ranged from 6.65 in B7 to $9.45 \%$ in B3. Comparable 7.96 and 8.74 to $14.22 \%$ protein contents were respectively reported by Okafor et al. (2012) in breads sold in Nigeria and Eke et al. (2013) in breads sold in Benue and Nassarawa States of Nigeria. Bread samples sold in Europe had 8.5\% protein (Ortega et al., 2013). Dietary proteins aids in synthesis of new cell, repair of worn-out tissues, enzymes, hormones, antibodies and other substances required for healthy functioning and development of the body and its protection (Alayande et al., 2012) and for the treatment of protein energy malnutrition. Fat content $(\%)$ differed significantly $(p<0.05)$ in the bread samples and ranged from 0.66 in B1 to 0.26 in B8. This range was within the maximum $\leq 2.0 \%$ specified for white bread in Nigeria (SON, 2004). Higher fat content of 1.69 and $1.5 \%$, though within the standard specification, were respectively reported by Okafor et al. (2012) and Ortega et al. (2013) in white bread sold in Nigeria. Fat increases the palatability of foods by absorbing and retaining flavours (Agu et al., 2010) and provides storage energy and transports fat-soluble vitamins, including vitamins A, D, E and K (Alayande et al., 2012).

Carbohydrate content significantly $(p<0.05)$ differed, ranging from 49.20 in B10 to $65.69 \%$ in B8. SON (2004) specified $\leq 48.0 \%$ carbohydrate in bread. Fiber content also differed significantly $(p<0.05)$ among the bread samples, from 1.24 in B5 to $1.76 \%$ in B2 (Table 3). Crude fiber aids in digestion; it slows down release of glucose into the blood and reduces the risk of colon cancer (Alayande et al., 2012).

Ash content $(\%)$ differed significantly $(p<0.05)$ in the bread samples, from 1.26 in B3 to $1.86 \%$ in B6. The bread samples had higher ash content than the minimum $\geq 0.6 \%$ recommended for white bread in Nigeria (SON, 2004). Higher 4.06 to $7.93 \%$ ash content was reported by Eke et al. (2013) on breads sold in Benue and Nassarawa States of Nigeria. Ash content indicates the quantity of minerals present in the product (Ugwuona, 2009; Igbabul et al., 2015).

\section{Mineral Composition of Bread Samples Consumed in Umuahia Metropolis}

Table 4 shows the mineral content of the bread samples. The bread samples were generally poor in minerals. Mineral contents in the bread samples ranged from 0.14 to $1.83 \mathrm{mg} 100 \mathrm{~g}^{-1}$. It was only zinc that was relatively high in the bread samples; and

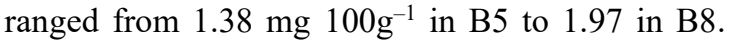
Potassium, magnesium and calcium were present in levels lower than $0.3 \mathrm{mg} 100 \mathrm{~g}^{-1}$. Phosphorus content was however higher than these values and ranged from 0.37 to $0.65 \mathrm{mg} 100 \mathrm{~g}^{-1}$ but much less than 1.0 $\mathrm{mg} 100 \mathrm{~g}^{-1}$ in all the samples. Phosphorus, potassium, magnesium and calcium were low; less than $1.0 \mathrm{mg} 100 \mathrm{~g}^{-1}$ in all the bread samples. So, these breads are not good sources of these minerals in the diet. It was only zinc content that was higher

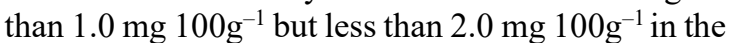
bread samples. Zinc is needed for effective working of the body's immune system (Wardlaw and Kessel, 2002), and aids in cell division, cell growth, wound healing, and the breakdown of carbohydrates (Champe and Harvey, 1994; Malomo et al., 2011).

Phosphorus content ranged from 0.37 to $0.68 \mathrm{mg}$ $100 \mathrm{~g}^{-1}$, potassium from 0.14 to $0.17 \mathrm{mg} 100 \mathrm{~g}^{-1}$, magnesium from 0.14 to $0.27 \mathrm{mg} 100 \mathrm{~g}^{-1}$ and calcium from 0.11 to $0.21 \mathrm{mg} 100 \mathrm{~g}^{-1}$ in the bread samples. Malomo et al. (2011) reported higher value of potassium (314.07 $\mathrm{mg} 100 \mathrm{~g}^{-1}$ ) and magnesium (138.80 mg $\left.100 \mathrm{~g}^{-1}\right)$.

\section{Presence of Potassium Bromate and Phyto- chemical Composition of the Bread Samples}

Table 5 shows status of potassium bromate and phytochemical composition of the bread samples. No potassium bromate was detected in any of the 10 (bread samples. Ekpo et al. (2008), some 12 years ago, detected some levels of bromate in bread sold in Uyo metropolis of Akwa Ibom State, Nigeria. Potassium bromate has been used as prominent dough improver in bread making, giving strength to dough during late proofing and early baking (Hoseney, 1990; Emeje et al., 2010). Unfortunately, in the early 1990's, the World Health Organization (WHO) discovered that potassium bromate does not digest on consumption and could cause cancer, kidney failure and several other related diseases (FAO/WHO, 1991). As a result, the use of bromate was later banned in many countries and Nigeria banned its use in 1993 (Emeje et al., 2010).

Table 4: Mineral composition of bread samples

\begin{tabular}{|c|c|c|c|c|c|}
\hline Samples ${ }^{*}$ & $\mathrm{P}\left(\mathrm{mg} 100 \mathrm{~g}^{-1}\right)$ & $\mathrm{K}\left(\mathrm{mg} 100 \mathrm{~g}^{-1}\right)$ & $\mathrm{Mg}\left(\mathrm{mg} 100 \mathrm{~g}^{-1}\right)$ & $\mathrm{Ca}\left(\mathrm{mg} 100 \mathrm{~g}^{-1}\right)$ & $\mathrm{Zn}\left(\mathrm{mg} 100 \mathrm{~g}^{-1}\right)$ \\
\hline $\mathrm{B} 1$ & $0.45 \pm 0.00^{\mathrm{f}}$ & $0.14 \pm 0.00^{\text {cd }}$ & $0.18 \pm 0.00^{\mathrm{e}}$ & $0.16 \pm 0.00^{\mathrm{d}}$ & $1.82 \pm 0.00^{\mathrm{c}}$ \\
\hline B2 & $0.52 \pm 0.00^{\mathrm{d}}$ & $0.16 \pm 0.00^{\mathrm{b}}$ & $0.17 \pm 0.00^{\mathrm{f}}$ & $0.14 \pm 0.00^{\mathrm{e}}$ & $1.63 \pm 0.00^{\mathrm{f}}$ \\
\hline B3 & $0.53 \pm 0.01^{\mathrm{d}}$ & $0.14 \pm 0.00^{\mathrm{c}}$ & $0.21 \pm 0.00^{\mathrm{c}}$ & $0.24 \pm 0.00^{\mathrm{a}}$ & $1.77 \pm 0.00^{\mathrm{d}}$ \\
\hline B4 & $0.47 \pm 0.00^{\mathrm{a}}$ & $0.17 \pm 0.00^{\mathrm{a}}$ & $0.14 \pm 0.00^{\mathrm{h}}$ & $0.11 \pm 0.00^{g}$ & $1.83 \pm 0.01^{\mathrm{c}}$ \\
\hline B5 & $0.53 \pm 0.00^{\mathrm{d}}$ & $0.17 \pm 0.00^{\mathrm{a}}$ & $0.15 \pm 0.00^{\mathrm{g}}$ & $0.14 \pm 0.00^{\mathrm{f}}$ & $1.38 \pm 0.00^{\mathrm{g}}$ \\
\hline B6 & $0.55 \pm 0.00^{\mathrm{c}}$ & $0.15 \pm 0.00^{\mathrm{b}}$ & $0.27 \pm 0.00^{\mathrm{a}}$ & $0.14 \pm 0.00^{\mathrm{e}}$ & $1.95 \pm 0.01^{\mathrm{a}}$ \\
\hline B7 & $0.58 \pm 0.00^{\mathrm{b}}$ & $0.14 \pm 0.00^{\mathrm{dc}}$ & $0.24 \pm 0.00^{\mathrm{b}}$ & $0.11 \pm 0.00^{\mathrm{g}}$ & $1.95 \pm 0.00^{\mathrm{a}}$ \\
\hline B8 & $0.37 \pm 0.00^{\mathrm{g}}$ & $0.14 \pm 0.00^{\mathrm{cd}}$ & $0.19 \pm 0.00^{\mathrm{d}}$ & $0.19 \pm 0.00^{\mathrm{c}}$ & $1.97 \pm 0.00^{\mathrm{a}}$ \\
\hline B9 & $0.55 \pm 0.00^{\mathrm{c}}$ & $0.14 \pm 0.01^{\mathrm{d}}$ & $0.17 \pm 0.00^{\mathrm{f}}$ & $0.11 \pm 0.00^{\mathrm{g}}$ & $1.63 \pm 0.00^{\mathrm{f}}$ \\
\hline $\mathrm{B} 10$ & $0.65 \pm 0.00^{\mathrm{a}}$ & $0.17 \pm 0.00^{\mathrm{a}}$ & $0.22 \pm 0.01^{\mathrm{c}}$ & $0.21 \pm 0.00^{\mathrm{b}}$ & $1.77 \pm 0.00^{\mathrm{e}}$ \\
\hline
\end{tabular}

"mean values and standard deviations of 3 determinations, a b c d e f g h - mean values with the same superscripts in a column are not significantly $(p>0.05)$ different, B1-B10 - bread samples of different brands 
Oxalate content $\left(\mathrm{mg} 100 \mathrm{~g}^{-1}\right)$ was low in all the bread samples and ranged from 0.66 in $\mathrm{B} 8$ to 0.95 in B2 and B5. Ekpo et al. (2008) reported higher levels of oxalate (17.60 to $\left.35.20 \mathrm{mg} 100 \mathrm{~g}^{-1}\right)$ in bread samples sold in Uyo, Akwa Ibom State of Nigeria. Oxalate binds with divalent cations namely $\mathrm{Ca}^{2+}$, $\mathrm{Mg}^{2+}, \mathrm{Zn}^{2+}$, making them unavailable for cell utilization. It also causes irritation to the digestive tract when such foods are eaten. High concentration of oxalate in the diets can increase the risk of kidney calcium absorption, resulting in renal calculus or kidney stone and hence, oxalate poisoning (Onyeike, 2012).

Tannin content was high and ranged from 87.78 in B5 to $125.40 \mathrm{mg} 100 \mathrm{~g}^{-1}$ in B7. Higher tannin contents of 111.91 to $129.82 \mathrm{mg} 100 \mathrm{~g}^{-1}$, and 121.48 to $126.22 \mathrm{mg} 100 \mathrm{~g}^{-1}$ were reported in breads sold in Uyo metropolis (Edet, 2005; Ekpo et al., 2008). High tannin content damage intestinal tract and reduce absorption of iron and other divalent metals, and may be carcinogenic (Onyeike, 2012). Recent research has shown that polyphenols/tannins and phytic acid at low concentrations increase immunity in animal and human against several diseases (Ratnavathi and Patil, 2013).

Phytate content $\left(\mathrm{mg} 100 \mathrm{~g}^{-1}\right)$ ranged from 2.02 to 3.03 in the bread samples. Higher phytate content of 288.00 to $297.29 \mathrm{mg}^{100 \mathrm{~g}^{-1}}$ was reported by Ekpo et al. (2008) in bread samples sold in Uyo metropolis of Akwa Ibom State, Nigeria. Phytate forms insoluble salts with divalent metal ions (calcium, magnesium, iron and zinc), rendering them unavailable for absorption into the body (Ratnavathi and Patil, 2013). Phytates also bind with proteolytic enzymes and form chelates with divalent metals, thereby making them unavailable (Eneobong, 2001; Ratnavathi and Patil, 2013).

\section{Sensory Characteristics of the Bread Samples}

Sensory scores of the various attribute of the bread samples are presented in Table 6. There were significant $(p<0.05)$ differences in sensory scores of the bread samples. Sensory properties are important aspect of food quality that influences consumers' attitudes and likings food products (Amuneke et al., 2020). Sample B13 was the most acceptable bread and had significantly high scores for appearance (7.75), texture (7.80), aroma (7.60) and overall acceptability (7.90). On the other hand, sample B9 had poor sensory scores ranging from 4.20 for aroma to 4.26 for appearance. This sample was most disliked and had 4.6 for overall acceptability. Other samples had sensory scores higher than 5 for the various sensory attributes. Samples B1, B4, B6, B7, B8, and B10 had equal acceptance on overall acceptability. The differences in sensory scores of the bread sample could be attributed to differences in recipes (quantity and types of ingredients used), and baking procedures for the different bread samples.

\section{CONCLUSION/RECOMMENDATIONS}

Laboratory analysis confirmed absence of potassium bromate in the bread samples as claimed on the labels. Reported values of nutrient compositions of the bread samples were lower than those inscribed on the bread label. Recipes with too many ingredients did not result in breads of outstanding quality. Micronutrients, including minerals and vitamins were low; very much lower than the values on the labels. However, proximate composition of the analyzed bread sample was within range of the required standard outlined by SON. Nigerians are encouraged to consume these breads. Bread makers are encouraged to give reproducible information on labels to build consumers' confidence on them.

Table 5: Potassium bromate and phytochemical composition of the bread samples

\begin{tabular}{lllll}
\hline Samples $^{*}$ & Potassium bromate & Oxalate $(\%)$ & Tannin $\left(\mathrm{mg}^{\mathrm{d}} \mathrm{gog}^{-1}\right)$ & Phytate $\left.\left(\mathrm{mg}^{\mathrm{d}}\right) \mathrm{g}^{-1}\right)$ \\
\hline B1 & ND & $0.93 \pm 0.00^{\mathrm{b}}$ & $108.01 \pm 0.01^{\mathrm{d}}$ & $2.06 \pm 0.00^{\mathrm{g}}$ \\
B2 & ND & $0.95 \pm 0.00^{\mathrm{a}}$ & $116.71 \pm 0.01^{\mathrm{b}}$ & $2.04 \pm 0.00^{\mathrm{h}}$ \\
B3 & ND & $0.72 \pm 0.01^{\mathrm{g}}$ & $97.08 \pm 0.00^{\mathrm{f}}$ & $2.02 \pm 0.00^{\mathrm{i}}$ \\
B4 & ND & $0.85 \pm 0.01^{\mathrm{e}}$ & $109.03 \pm 0.00^{\mathrm{c}}$ & $2.97 \pm 0.00^{\mathrm{b}}$ \\
B5 & ND & $0.95 \pm 0.00^{\mathrm{a}}$ & $87.78 \pm 0.00^{\mathrm{i}}$ & $2.38 \pm 0.00^{\mathrm{d}}$ \\
B6 & ND & $0.87 \pm 0.00^{\mathrm{c}}$ & $94.44 \pm 0.00^{\mathrm{h}}$ & $2.15 \pm 0.00^{\mathrm{f}}$ \\
B7 & ND & $0.86 \pm 0.00^{\mathrm{de}}$ & $125.40 \pm 0.01^{\mathrm{a}}$ & $2.04 \pm 0.01^{\mathrm{h}}$ \\
B8 & ND & $0.66 \pm 0.00^{\mathrm{h}}$ & $94.69 \pm 0.01^{\mathrm{g}}$ & $2.79 \pm 0.00^{\mathrm{c}}$ \\
B9 & ND & $0.86 \pm 0.00^{\mathrm{cd}}$ & $101.61 \pm 0.01^{\mathrm{e}}$ & $3.03 \pm 0.00^{\mathrm{a}}$ \\
B10 & $0.83 \pm 0.01^{\mathrm{f}}$ & $94.45 \pm 0.01^{\mathrm{h}}$ & $2.25 \pm 0.00^{\mathrm{e}}$ \\
\hline
\end{tabular}

"mean values and standard deviations of 3 determinations, a b c d e f g h i - mean values with the same superscripts in a column are not significantly $(p>0.05)$ different, ND - not detected, B1-B10 - bread samples of different brands.

Table 6: Sensory characteristics of the bread samples

\begin{tabular}{llllll}
\hline Samples $^{*}$ & Colour & Texture & Taste & Aroma & Overall acceptability \\
\hline B1 & $7.75 \pm 0.91^{\mathrm{a}}$ & $7.80 \pm 0.83^{\mathrm{ab}}$ & $7.55 \pm 1.00^{\mathrm{ab}}$ & $7.60 \pm 0.88^{\mathrm{ab}}$ & $7.90 \pm 0.91^{\mathrm{a}}$ \\
B2 & $6.05 \pm 1.32^{\mathrm{c}}$ & $6.10 \pm 1.29^{\mathrm{ef}}$ & $5.90 \pm 0.97^{\mathrm{cd}}$ & $6.15 \pm 0.93^{\text {de }}$ & $5.95 \pm 1.40^{\mathrm{c}}$ \\
B3 & $6.30 \pm 1.22^{\mathrm{bc}}$ & $6.15 \pm 1.42^{\text {def }}$ & $5.80 \pm 1.82^{\mathrm{d}}$ & $5.80 \pm 1.60^{4 \mathrm{e}}$ & $6.00 \pm 1.41^{\mathrm{c}}$ \\
B4 & $7.15 \pm 1.27^{\mathrm{ab}}$ & $7.10 \pm 1.21^{\mathrm{abcd}}$ & $6.90 \pm 1.52^{\mathrm{bc}}$ & $6.70 \pm 1.17^{\mathrm{bcde}}$ & $7.20 \pm 1.11^{\mathrm{ab}}$ \\
B5 & $6.40 \pm 1.35^{\mathrm{bc}}$ & $5.95 \pm 1.28^{\mathrm{f}}$ & $6.05 \pm 1.47^{\mathrm{cd}}$ & $6.05 \pm 1.32^{\text {de }}$ & $6.30 \pm 1.26^{\mathrm{bc}}$ \\
B6 & $7.05 \pm 1.57^{\mathrm{abc}}$ & $6.65 \pm 1.35^{\text {cdef }}$ & $6.65 \pm 1.57^{\mathrm{bcd}}$ & $6.30 \pm 1.75^{\text {cde }}$ & $7.20 \pm 1.58^{\mathrm{ab}}$ \\
B7 & $7.20 \pm 1.54^{\mathrm{ab}}$ & $7.05 \pm 1.19^{\mathrm{bcde}}$ & $7.20 \pm 1.51^{\mathrm{ab}}$ & $6.90 \pm 1.29^{\mathrm{bcd}}$ & $7.25 \pm 1.41^{\mathrm{a}}$ \\
B8 & $7.75 \pm 1.25^{\mathrm{a}}$ & $8.05 \pm 1.32^{\mathrm{a}}$ & $8.00 \pm 1.34^{\mathrm{a}}$ & $8.05 \pm 1.32^{\mathrm{a}}$ & $8.10 \pm 1.07^{\mathrm{a}}$ \\
B9 & $4.65 \pm 2.54^{\mathrm{d}}$ & $4.80 \pm 2.31^{\mathrm{g}}$ & $4.35 \pm 1.98^{\mathrm{a}}$ & $4.20 \pm 2.04^{\mathrm{f}}$ & $4.60 \pm 2.14^{\mathrm{d}}$ \\
B10 & $6.25 \pm 1.48^{\mathrm{bc}}$ & $7.25 \pm 1.45^{\mathrm{abc}}$ & $7.20 \pm 1.61^{\mathrm{ab}}$ & $7.20 \pm 1.24^{\mathrm{abc}}$ & $7.45 \pm 1.28^{\mathrm{a}}$ \\
\hline
\end{tabular}

${ }^{*}$ mean values and standard deviations of 3 determinations, a b c d e f g - mean values with the same superscripts in a column are not significantly $(p>0.05)$ different, B1-B10 - bread samples of different brands. 


\section{REFERENCES}

Agu H.O., Ukonze J.A. and Paul K.A. (2010). Quality characteristics of bread made from wheat and fluted pumpkin seed flour. Nig. Food J., 28, 188-198

Alayande L.B., Mustapha K.B., Dabak J.D. and Ubom G.A. (2012). Comparison of nutritional values of brown and white beans in Jos North Local Government markets. Afr. J. Biotechnol., 11 (43), 10135-10140

Amuneke K.E., Oguntade O.R., Ikeogu F.C. and Nomeh U.A. (2020). Effect of natural preservatives on the organoleptic characteristics and storage stability of smoked Heterotis niloticus. Agro-Science, 19 (2), 31-35

Anyika J.U. and Uwaegbute A.C. (2005). Frequency of consumption and nutrient content of some snacks eaten by adolescent secondary and university students in Abia State. Nig. J. Nutr. Sci., 26, 10-15

AOAC (2005). Official Method of Analysis (1 $7^{\text {th }}$ ed.), Association of Official Analytical Chemists, Washington DC

Brown J. (1993). Advances in breadmaking technology. In: Kamel B.S. and Stauffer C.E. (eds.), Advances in Baking Technology (pp. 38-87). Dordrecht NY: Springer Science and Business Media

Cauvain S.P. (2015). Technology of Breadmaking. Springer Intl. Publishing, London

Champe P.C. and Harvey R.A. (1994). Lippincott's Illustrated Reviews: Biochemistry ( $2^{\text {nd }}$ ed.), Lippincott Raven Publishers, Philadelphia, pp. 303-340

Doyle M.E. and Glass K.A. (2010). Sodium reduction and its effect on food safety, food quality and human health. Comparat. Rev. Food Sci., 9 (1), 44-56

Ebuchi A.E. and Oyewole C.O. (2007). Effect of cooking and soaking on physical characteristics, nutrient composition and sensory evaluation of indigenous and foreign rice varieties in Nigeria. Afr. J. Biotechnol., 6 (8), 1016-1020

Ebuehi O.A.T., Owolabi O.O., Ikanone C.E., Amabibi I.T.T. and Ajekwu A.P. (2007). Organoleptic, mineral and vitamin evaluation of some Nigerian bread. Nig. Food J., 25 (2), 95-100

Edema M.O., Sanni L.O. and Sanni A. (2004). Evaluation of plantain flour blends for plantain bread production in Nigeria. Afr. J. Biotechnol., 4 (7), 911-918

Edet U.E. (2005). Nutrient Contents of Breads. An Undergraduate Dissertation, University of Uyo, Nigeria, $48 \mathrm{pp}$.

Eke M.O., Ariahu C.C. and Gernah D.I. (2013). Chemical and sensory evaluation of bread sold in Benue and Nassarawa States of Central Nigeria. Adv. J. Food Sci. Technol., 5 (5), 547-550

Ekpo A.S., Obot I.B. and Ikpatt E.N. (2008). Antinutritional factors and potassium bromate content in bread and flour samples in Uyo Metropolis. Nig. Food J., 5 (4), 736-741

Emeje M.O., Ofoefule S.I., Nnaji A.C., Ofoefule A.U. and Brown S.A. (2010). Assessment of bread safety in Nigeria: Quantitative determination of potassium bromate and lead. Afr. J. Food Sci., 4 (6), 394-397

Eneobong H.N. (2001). Eating Right (A Nutrition Guide), Zoometer Print Communications Ltd, Nigeria, $86 \mathrm{pp}$

FAO/WHO (1991). Energy and protein requirements. Protein Evaluation Report of Joint FAO/WHO Expert Consultation. FAO Food \& Nutri. Paper, Rome 51, 247

Hoseney C.R. (1990). Structure of cereals. In: Principles of Cereals Science and Technology. St Paul MN: American Association of Cereal Chemists

Igbabul B.D., Iorliam B.M. and Umana E.N. (2015). Physicochemical and sensory properties of cookies produced from composite flours of wheat, cocoyam and African yam beans. J. Food Res., 4 (2), 150-158

Kansas (2006). Wheat letter. Seminar on Wheat Importation in Nigeria by Kansas Wheat Commission, $18^{\text {th }}$ May, Kansas Association of Wheat Growers, Manhattan, Kansas Ltd., Nigeria
Kirk R.S. and Sawyer R. (1991). Pearson's Composition and Analysis of Foods ( $9^{\text {th }}$ ed.), Longman Limited, Addision Wealey, pp. 33-36

Malomo S.A., Eleyinmi A.F. and Fashakin J.B. (2011). Chemical composition, rheological properties and bread making potentials of composite flours from breadfruit, breadnut and wheat. Afr. J. Food Sci., 5 (7), 400-410

Meilgaard M., Civille G.V. and Carr B.T. (1999). Sensory Evaluation Techniques ( $3^{\text {rd }}$ ed.), CRC Press LLC, NY

Michael D. (2006). Nigeria grain and feed annual report. USDA Foreign Agricultural Service, Global Agriculture Information Network, pp. 1-11

Niseteo T., Kornes D., Belscak-Cvitanovic A., Horzic D. and Budec M. (2012). Bioactive composition and antioxidant potential of different commonly consumed coffee brews affected by their preparation technique and milk addition. Food Chem., 134, 1870-1877

Okafor J.N.C., Okafor G.I., Ozumba A.U. and Elemo G.N. (2012). Quality characteristics of bread made from wheat and Nigerian oyster mushroom (Pleurotus plumonarius) powder. Pak. J. Nutr., 11 (1), 5-10

Oke O.L. (1966). Chemical studies on the more commonly used vegetables in Nigeria. J. West Afr. Sci. Assoc., 11, $42-48$

Olaoye O.A., Onilude A.A. and Idowu O.A. (2006). Quality characteristics of bread produced from composite flours of wheat, plantain and soybeans. $A f r$. J. Biotechnol., 5 (11), 1102-1106

Onuegbu N.C., Ihediohanma N.C., Odunze O.F. and Ojukwu M. (2013). Efficiency of wheat: Maize composite flour as affected by baking method in bread and cake production. Sky J. Food Sci., 2 (8), 5-13

Onuegbu N.C., Onyeka E.U. and Agbaji D. (2007). Evaluation of African black pear pulp and oil as ingredients in bread production. Nig. Food J., 25, 171-172

Onyeike E.N. (2012). Food, nutrition and toxicology: Is your life in your hands? Inaugural Lecture No. 99 (pp. 65-72), Department of Biochemistry, Faculty of Science, University of Port Harcourt, $13^{\text {th }}$ Dec. 2012

Ortega R., López A.M., Requejo A.M. and Carvajales P.A. (2013). European Food Information Council. La Alimentación Española: Características nutricionales de los principales alimentos de nuestradieta. Ministerio de Agricultura, Pescay Alimentación, pp. 1-4

Poitrenaud B. (2004). Bakers' yeast. In: Hui Y.H., Meunier-Goddik L., Hansen Å.S. et al. (eds.), Handbook of Food and Beverage Fermentation Technology (pp. 1-25). New York: Marcel Dekker Incorporation

Randez-Gil F., Sanz P. and Prieto J.A. (1999). Engineering baker's yeast: Room for improvement. Trends Biotechnol., 17, 237-244

Ratnavathi C.V. and Patil J.V. (2013). Sorghum utilization as food. J. Nutr. Food Sci., 4 (1), 247-253

Rose A.H. and Vijayalakshmi G. (1993). Bakers' yeasts. In: Rose A.H. and Harrison J.S. (eds.), The Yeasts: Yeast Technology $2^{\text {nd }}$ ed. (pp. 357-397). London: Academic Press

Selomulyo V. O. and Zhou W. (2007). Frozen bread dough: Effect of freezing storage and dough improvers. J. Cereal Sci., 45, 1-17

SON (2004). Standard for bread. Nigeria Industrial Standards (NIS), Standard Organization of Nigeria, Abuja

SPSS (2007). Statistical package for special services, Version 16. Guide for Personal Computer, Chicago

Ugwuona F.U. (2009). Chemical and sensory evaluation of soy-fortified cassava wheat biscuit. Agro-Science, 8 (1), 55-59

Wardlaw G.M. and Kessel M. (2002). Perspective in Nutrition ( $5^{\text {th }}$ ed.), McGraw-Hill, New York 